\title{
Push and Pull Factor: Determining the visitors' satisfactions at urban recreational area
}

\author{
Noralizawati Mohamed, Noriah Othman \\ Department of Landscape Architecture, Faculty of Architecture, Planning and Surveying, \\ Universiti Teknologi MARA, 40000 Shah Alam, Selangor, Malaysia \\ leezmohd@yahoo.com
}

\begin{abstract}
This study investigates the visitors' satisfaction at the most popular urban recreational area, Kepong Metropolitan Park, Selangor. It presents the analysis and synthesis of information collected from an open-ended survey. Selected visitors were asked to state their opinions regarding overall scene and the answers were summarized and categorized in terms of several dimensions. As a result, the researcher found that the visitors expressed several comments and suggestions that could be used as push and pull factors in determining their satisfaction in the recreational area. These two dimensional phenomenons are very useful as reference to researchers or designers to identify and fulfill the visitors' satisfaction for future preparation of recreational area.

Keywords: Push and Pull Factor, Visitor Satisfaction, Urban Recreation Area, Open-ended Survey

eISSN 2514-751X @ 2016 The Authors. Published for AMER ABRA by e-International Publishing House, Ltd., UK.. This is an open access article under the CC BY-NC-ND license (http://creativecommons.org/licenses/by-ncnd/4.0/). Peer-review under responsibility of AMER (Association of Malaysian Environment-Behaviour Researchers), ABRA (Association of Behavioural Researchers on Asians) and cE-Bs (Centre for EnvironmentBehaviour Studies), Faculty of Architecture, Planning \& Surveying, UniversitiTeknologi MARA, Malaysia.

https://doi.org/10.21834/aje-bs.v1i1.169
\end{abstract}




\subsection{Introduction}

For years, Malaysian government has been aggressive in developing more recreational spots in urban areas. The completed programmes have reported invaluable contribution towards Garden Nation Vision besides providing a good living for urban people and produce more green spaces for urban environment. These recreational areas are of great assets for the cities and urbanities (Sreetheran, 2007) and they are created to preserve the natural environment (Ismail, 2002), as place for people to experience nature (Cohen et al., 2007), to release from stress and gain a positive psychological effect (Noralizawati, 2009).

It is predicted that by the year $2020,73 \%$ of the Malaysian population will be urbanites (Nor A'aini and Kamarul'ain, 2007), thus it shows that Malaysians will live in urban neighborhood and share the same benefits obtained from the recreational areas. In the same year, forum at International Federation of Landscape Architecture (IFLA), had revealed that urban people are becoming more aware towards the quality of the recreational areas.

According to that matter, the National Landscape Department had taken another advance step to raise and upgrade the quality of many recreational areas to become more livable and sustainable green area. The considerations that have been taken are the producing of an ecological design approach, following the rules of sustainable landscape construction, selecting the suitable plant species and landscape amenities and being responsive towards the social and cultural needs of around the area. However, can an excellent design of the existing recreational areas guarantee the public satisfaction needs in the long term?

Therefore, realizing the gap of knowledge, the researcher chose the Kepong Metropolitan Park, Selangor as a site study in order to measure the satisfaction level of the visitors towards the area. The research findings were categorized into push factors and pull factors in the comprehensive table to be used as reference for landscape architecture industries, designers and researchers in the future.

\subsection{Literature Review}

In the study of urban recreational area, there have been a number of research on the visitors satisfaction which showed visitors preferred the landscape in recreation area that perceived as natural and environmental friendly (Chiesura, 2004; Jorgensen, 2004; Oku and Fukamachi, 2005; Ozguner and Kendle, 2006; Noralizawati, 2009). Previous research survey such as in Malaysia (Noralizawati, 2009), China (Yu, 1995), Japan (Oku and Fukamachi, 2005) and America (Mustafa, 1994) and United Kingdom (Ozguner and Kandle, 2006) has revealed a significant relationship between the visitors and urban recreational area in context of public satisfaction needs.

The studies across the globe have suggested many ways to improve the appearances of the recreational park where visitors preferred and feel more satisfied. For example, 
Noralizawati (2009) had discovered that safety was the first criteria chosen by the visitors to determine their satisfaction level in FRIM Recreation Park, Malaysia. Surveyed in Sapporo Park, Japan by Todorova et.al., (2002) found that the street plantings as a factor that contributed to the aesthetic quality and bring self satisfaction to the female users. Cohen et. al., (2007) in United States Park added that the male users were more attracted to the sports facilities while female appreciated the playground for their kids. In Sheffield Park, United Kingdom, Ozguner and Kendle (2006) agreed that the respondents preferred recreational park that visualized neat and tidy approach.

Although there is an increasing interest in urban recreation area, it is also evident that some people do not respond well and give negatives feedback such as, the place is untidy, lack of facilities and plants maintenance, unsafe for women and sometimes too crowded at certain time (Cohen et. al., 2007; Daunmants, 2004; Kaplan, 1984; Ozguner and Kendle, 2006). Noralizawati (2009) found that the park users were dissatisfied with the sounds coming from the urbanization activities which would break their concentration while visiting the recreational park. Azlin and Sabri (1997) noticed that some professional respondents did not like denseness because it would result to an environmental destruction around the recreation area.

The literature on outdoor recreation area indicates that motivations based on the concept of push and pull factors generally have been accepted (Chiesura, 2004; Daunmants, 2004; Jorgensen, 2004; Oku and Fukamachi, 2005; Ozguner and Kendle, 2006). Push factors are considered to be those sociopsychological constructs related to the visitors and their environments that predispose the individual to visit the recreation area and explain the desire of their satisfaction need. Pull factors, on the other hand, are the recreation area that having attributes that reflect to an individual to stay away from the recreation area.

\subsection{Methodology}

The survey was administrated on May 2008. There were 181 respondents participated in this survey and were interviewed face to face by the researcher. According to Sekaran (2003), this approach would bring advantages to the researcher where the researcher can adapt the questions as necessary, clarify any doubts and ensure that the responses are properly understood. This number of respondents is sufficient based on a statistical table by Krejcie and Morgan (1970) cited from Sekaran (2003). They suggested that, if the population $(\mathrm{N})$ is 34 the sample size $(\mathrm{n})$ should be 181.

The research instruments utilized in this study were developed to gauge the level of visitor's satisfaction of the study area. Section A deals with questions on the demographic background of the respondents. Section B deals with 10 photographs natural elements of the study area. Under this section, the respondents were asked to thick weather they are satisfied or not satisfied with the sceneries showed in the photographs and give their 
reasons for each answer through an open-ended question. For collection and selection of landscape photographs, this research applied an environmental sampling technique as introduced by Kaplan and Kaplan (1989). According to them, grouping the criteria in the selection of photographs of the site is needed because people react to what they experience in terms of commonalities, classes and categories.

The content analysis was carried out based on the satisfaction results and open ended comments by the respondents. The keywords described in the answers were listed and ranked according to their percentage of the total number of keywords in each category. Finally, the answers were grouped into the push factors and pull factors accordingly.

\subsection{Results and Discussions}

\subsection{Values and Benefits Experienced}

The open ended answers provided by the respondents addressed some similar reasons that influenced their satisfaction feelings towards the given photographs. The majority of respondents felt that the Kepong Metropolitan Park offered a high value and benefits experiences for them such as place to observe and get close with nature (27.0\%), peaceful and quiet $(22.0 \%)$, relieve from stress $(20.0 \%)$, social space $(17.0 \%)$ and sense of life $(14.0 \%)$.

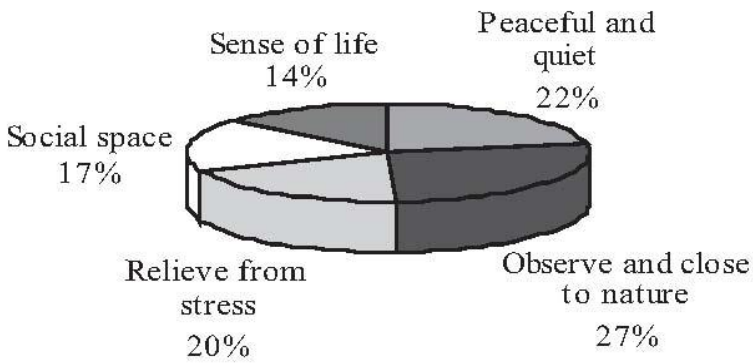

Figure 1: Chart Showing the Percentage of Values and Benefits Given by the Respondents at Kepong Metropolitan Park (Source: Author, 2009)

\subsection{Push Factors}

The photographs that were categorized under natural elements such as 1) lake, 2) lawn, 3) groundcovers, 4) shrubs, 5) trees, 6) palms, 7) flowers and planting bed, 8) natural path, 9) natural stones and 10) birds and insects.

The result showed a great satisfaction of the respondents towards the lake $(90.0 \%)$, flowers and planting bed (82.3\%), birds and insects $(75.0 \%)$, trees $(70.0 \%)$, natural stones $(66.7 \%)$ and palms (60\%). 
It has been agreed in previous research that the lake is found to bring positive psychological benefits such as cooling and refreshing and it becomes the reason to influence the respondents' satisfaction in the recreational area (Coeterier et al., 1997; Chiesura, 2004). Noralizawati (2009) reported in her research finding that the feeling of being one with nature was specially evoked by landscapes exploration with water element.

For trees elements, the respondents were satisfied with the size of the trees that could provide sufficient shade for them. They also preferred the trees and palms sceneries because of the numbers that created diversity. This was identified by Hull and Hervey (1989), where maturity and density of the trees are positively related to increased feelings of pleasure in the environment. Besides density, the researcher also believes that the respondents were attracted to the scenes because of their greenness. According to Bevlin (1994), green is a cool colour that symbolizes nature and it evokes a feeling of calmness in people. In landscape studies, colour is appreciated in the foliage, flowers, trunk, fruits and branches of a particular plant (Dawson, 1988). The natural stones located along the walkway also brought satisfaction to the respondents. According to them, the elements looked natural, organic shape and real besides could add a value of aesthetic on the ground surfaces.

Flowers and planting bed were also one of the universal favorites by the recreational users. The respondents addressed that they were very satisfied with the planting design, species of the flowers and smell of the area. A few respondents stated that they liked the smell of plants while walking along the trail and made the place unforgettable. Based on the comments above, the researcher found that this is closely related to the concept of genius loci. Genius loci is the tangible quality which contributes to the identity of place and helps one to determine the differences between one place from another (Bell, 1993). In addition, birds and wildlife could be dismissed by the respondents while visiting the area. In this study, the satisfaction showed by the visitors were associated with the feeling of caring and loving towards the creatures.

\subsection{Pull Factors}

A slightly difference of percentage could be seen for the lawn (70.3\%), groundcovers $(65.1 \%)$, shrubs $(58.0 \%)$ and natural path $(51.2 \%)$. It could be considered that the respondents were not really satisfied with the natural elements due to certain reasons.

Statistic showed that majority of the respondents were not satisfied with the condition of lawn in the photograph and the reality. They seemed to give negative comments such as untrimmed grass, produced messy visual quality and unsafe feeling towards the scenery. Ozguner and Kandle (2006) highlighted in their study that negative feelings are always related with unorganized landscape character and less preferred by the people. Based on the finding, researcher identified that the lawn was designed for the public to express themselves and do social activities. The existing lawn as foreground that provides openness and gives an opportunity for the visitors to view towards the beautiful scenery while they are having their activity. However, the failure of landscape maintenance aspects 
had produced bad scenery and dissatisfaction among the visitors.

The same situation also reported for groundcovers and shrubs sceneries. Both elements required more concentration after planted on the ground. The respondents mentioned that the groundcovers and shrubs were not well trimmed therefore they looked dull, unhealthy and produced negative impression towards them. They found that all the planting scenes in the photographs were very dull, the leaves were scattered, unhealthy and the surrounding was badly maintained. This produced a feeling of boredom thus creating very little excitement.

According to Kaplan and Kaplan (1998), the arrangement of space could make environments more interesting and attractive, thus, the researcher feels that some improvements should be done to make the scene better. The researcher suggests that a variety of plants be planted taking into consideration the hierarchy of height to increase volume in the scene. A relative amount of vegetation should also be planted in the background, middle ground and foreground to create hierarchy which is also another important component of the view (Patsfall et al., 1984). For unhealthy plants, watering and fertilizing should follow a better maintenance of work schedule.

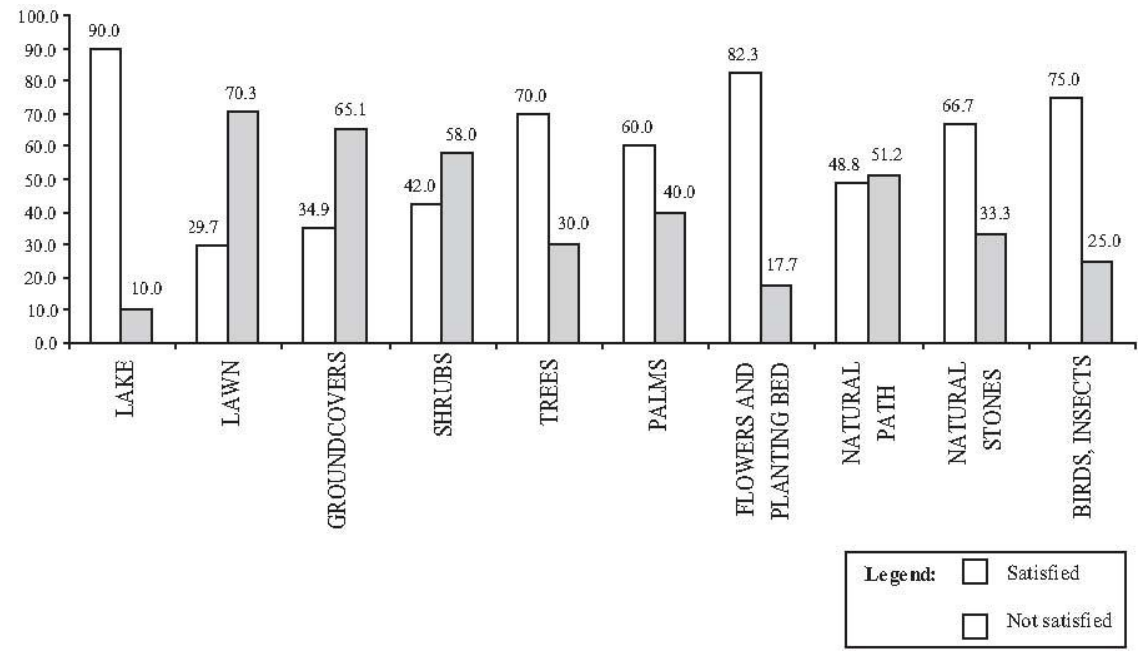

Figure 2: Chart Showing the Percentage of Satisfied and Not Satisfied Visitors towards Natural Elements at Kepong Metropolitan Park

(Source: Author, 2009) 


\subsection{Conclusion}

By looking at the findings of the study, it can be concluded that the natural elements in Kepong Metropolitan Park can measure the level of visitors satisfaction differently. As underlined in previous section, the factors that influenced or pushed the visitors to visit the place are associated with the elements that appear as beautiful, cooling, well maintained and organized which also include their enormous appreciation towards animals. Beside the physical characteristic, the values and benefits of the areas such as peaceful and quiet, relieve from stress and can get close to nature are also associated with their feeling of satisfaction too. Other pulling factors that influenced the visitors satisfaction towards the natural elements are the maintenance and management of the area. Clearly, unsafe and not well maintained surroundings are giving negative impact on the visitors satisfaction. It is hoped that the unsatisfied natural elements in this study area can be upgraded so that it finally be able to tackle the visitors satisfaction in a positive way in the future.

\section{Acknowledgement}

This study was made possible by the continuous support of Universiti Teknologi MARA, Malaysia

\section{References}

Azlin, Y., \& Sabri, N. (1997). Forest recreation environment: Visitors preferences and perceptions. FRIM, 1(1), 112.

Bell, S. (1993). Elements of visual design in the landscape. E \& FN Spon.

Bevlin, M. E. (1994). Design through discovery: The elements and principles. Harcourt Brace College Pub.

Chiesura, A. (2004). The role of urban parks for the sustainable city. Landscape and Urban Planning, 64, 129-138.

Coeterier, F., Ploeger, B., Schone, M. B., \& Buijs, A. (1997). Perception of the Waddensea area: Investigating the values of visitors and inhabitants. In Chiesura, A., The role of urban parks for the sustainable city. Landscape and Urban Planning, 64, 129-138.

Cohen, D., McKenzie, T., Sehgal, A., \& Williamson, S. (2007). Contribution of public parks to physical activity. American Journal of Public Health, 97, 509-514.

Daunmants, L. (2003). Factors affecting visual preferences for naturalization and restoration in urban park landscapes. Dissertation Abstracts International (UMI No. 766661971). Retrieved September 19, 2007 http://wwwlib.umi.com/dissertations/fullcit766661971.

Dawson, J. R. (1988). (December, 1988).Aesthetic factors to consider in the placement and selection of trees. Turf Craft Australia, 44-47. Retrieved October 19, 2007, from http://www.envirolinks.com.au/articles.html. 
Hull, R. B., \& Harvey, A. (1989). Explaining the emotion people experience in suburban parks. Environment and Behavior, 21 (3), 323-345.

Ismail, N. (2002). Professional handbook for landscape architect. Institute of Landscape Architects Malaysia Pub.

Jorgenson, A., Hitchmough, J., \& Calvert, T. (2002). Woodland spaces and adges: Their impact on perception of safety and preference. Landscape and Urban Planning, 60, 135-150.

Kaplan, R. (1984). Impact of urban nature: A theoretical analysis. Urban ecology, 8, 189-197.

Kaplan, R., \& Kaplan, S. (1989). The experience of nature: A psychological perspective. New York: Cambridge University Press.

Mustafa, K. M. S. (1994). A cross- cultural comparison of visual landscape preferences for the natural environment. Unpublished doctoral dissertation, Colorado State University.

Nor' A aini, O., \& Kamarul Ain, K. (2007, November). Keeping the green in urban area: An approach towards sustainable development. Paper presented at the Seminar Kebangsaan Rupabandar Malaysia, Perak, Malaysia.

Oku, H., \& Fukamachi, K. (2006). The differences in scenic perception of forest visitors through their attributes and recreational activity. Landscape and Urban Planning, 75, 34- 42.

Ozguner, H., \& Kendle, A. D. (2006). Public attitudes towards naturalistic versus designed landscapes in the city of Sheffield (UK). Landscape and Urban Planning, 74, 139- 157.

Sekaran, U. (2003). Research methods for business: A skill building approach. John Wiley and Sons, Inc.

Sreetheran, M., \& Kamariah, D. (2007). Performance indicators to evaluate urban parks from the saftey and security perspective. Paper presented at the Seminar Kebangsaan Rupabandar Malaysia from 28th to 29th November 2007. Lumut, Perak.

Todorova, A., Asakawa, S., \& Aikoh, T. (2004). Preferences for and attitudes towards street flowers and trees in Sapporo, Japan. Landscape and Urban Planning, 69, 403- 416. 